\title{
Exendin-4 inhibits glucolipotoxic ER stress in pancreatic $\beta$ cells via regulation of SREBP1C and C/EBP $\beta$ transcription factors
}

\author{
Yoon Sin Oh ${ }^{1,4, *}$, Youn-Jung Lee ${ }^{1, *}$, Yup Kang ${ }^{2}$, Jaeseok Han ${ }^{3}$, Oh-Kyung Lim ${ }^{5}$ \\ and Hee-Sook Jun ${ }^{1,6}$ \\ ${ }^{1}$ Lee Gil Ya Cancer and Diabetes Institute, Gachon University, 7-45 Songdo-dong, Yeonsu-ku, Incheon, Korea \\ ${ }^{2}$ Department of Endocrinology and Metabolism, Ajou University School of Medicine, Suwon, Korea \\ ${ }^{3}$ Howard Hughes Medical Institute, University of Michigan Medical Center, Ann Arbor, Michigan, USA \\ ${ }^{4}$ Gachon Medical Research Institute, Gil Hospital, Incheon, Korea \\ ${ }^{5}$ Department of Rehabilitation Medicine, Gil Hospital, Incheon, Korea \\ ${ }^{6}$ College of Pharmacy, Gachon University, Incheon, Korea \\ $*$ (Y S Oh and Y-J Lee contributed equally to this work)
}

\author{
Correspondence \\ should be addressed to \\ H-S Jun \\ Email \\ hsjun@gachon.ac.kr
}

\begin{abstract}
Prolonged exposure to high glucose (HG) and palmitate (PA) results in increased ER stress and subsequently induces $\beta$-cell apoptosis. Exendin-4, a glucagon-like peptide- 1 agonist, is known to protect $\beta$ cells from toxicity induced by cytokines, HG, or fatty acids by reducing ER stress. However, the detailed molecular mechanisms for this protective effect are still not known. In this study, we investigated the role of exendin-4 in the inhibition of glucolipotoxicity-induced ER stress and $\beta$-cell apoptosis. Exendin- 4 treatment protected INS- $1 \beta$ cells from apoptosis in response to HG/PA ( $25 \mathrm{mM}$ glucose $+400 \mu \mathrm{M}$ PA). HG/PA treatment increased cleaved caspase- 3 and induced ER stress maker proteins such as PERK (EIF2AK3), ATF6, and phosphorylated forms of PERK, eIF2 $\alpha$, IRE1 $\alpha$ (ERN1), and JNK (MAPK8), and these increases were significantly inhibited by exendin-4 treatment. HG/PA treatment of INS-1 cells increased SREBP1 (SREBF1) protein and induced its nuclear translocation and subsequently increased C/EBP $\beta$ (CEBPB) protein and its nuclear translocation. Exendin-4 treatment attenuated this increase. Knockdown of SREBP1c reduced the activation of CIEBP $\beta$ and also blocked the expression of ER stress markers induced by HG/PA treatment. Our results indicate that exendin- 4 inhibits the activation of SREBP1C and C/EBP $\beta$, which, in turn, may reduce glucolipotoxicity-induced ER stress and $\beta$-cell apoptosis.
\end{abstract}

Journal of Endocrinology (2013) 216, 343-352

\section{Introduction}

$\beta$-Cell mass regulation is a critical issue for understanding diabetes, a disease characterized by absolute (type 1) or relative deficiency (type 2 ) in the number of pancreatic $\beta$ cells. The loss of $\beta$-cell mass can be affected by environmental factors such as lipotoxicity and glucotoxicity (Poitout \& Robertson 2008). The chronic hyperglycemia and hyperlipidemia cause combined detrimental effects on $\beta$-cell function and survival, 
which is defined as glucolipotoxicity (Robertson et al. 2004). Several potential mechanisms underlying $\beta$-cell dysfunction caused by glucolipotoxicity have been suggested, including reactive oxygen species-mediated oxidative stress, inflammatory signals, lipid intermediates, and ER stress (Donath et al. 2005).

Attention has recently been directed to ER stress because the ER is highly developed in pancreatic $\beta$ cells due to their insulin secretory activity (Araki et al. 2003, Donath et al. 2005). Moreover, recent observations suggested that the ER may be responsible for the molecular mechanisms of glucolipotoxicity that contribute to $\beta$-cell dysfunction in type 2 diabetes (Weber et al. 2004).

To restore normal function after disturbed ER homeostasis, cells activate a protective mechanism known as the unfolded protein response, which involves doublestranded RNA-activated protein kinase RNA-like kinase (PERK), activating transcription factor 6 (ATF6), and inositol requiring enzyme 1 (IRE1) pathways (Wu \& Kaufman 2006, Lai et al. 2007), which may contribute to $\beta$-cell apoptosis.

Transcription factors such as sterol regulatory element binding proteins (SREBPs) and peroxisome proliferatoractivated receptor are known to be involved in ER stressactivated cell death (Weber et al. 2004, Wang et al. 2005). Chronic treatment with high glucose (HG), as well as ER stress inducers, is known to cause SREBP1c processing and activation (Foretz et al. 1999, Ye et al. 2000), and an increase in SREBP1c is correlated with $\beta$-cell glucolipotoxicity (Wang et al. 2005). As well, CCAAT-enhancer binding protein $(\mathrm{C} / \mathrm{EBP})$, one of the transcription factors regulating lipogenic gene expression, is induced upon chronic exposure to HG concentration (Plaisance et al. 2009).

Glucagon-like peptide-1 (GLP1), a potent glucoincretin hormone, has an antidiabetic function. It enhances glucose-dependent insulin release, insulin biosynthesis, and $\beta$-cell proliferation and suppresses $\beta$-cell apoptosis (Doyle \& Egan 2007). Exendin-4, a GLP1 receptor agonist, has been reported to enhance $\beta$-cell survival when exposed to streptozotocin, cytokine, or fatty acid (Tourrel et al. 2001, Ferdaoussi et al. 2008), and to have a protective effect on $\beta$-cell death through the activation of protein kinase B/AKT via the CREB pathway (Jhala et al. 2003).

In this study, we investigated the protective effect of exendin- 4 on glucolipotoxic ER stress on INS-1 $\beta$ cells, particularly on lipogenic transcription factor SREBP1c and C/EBP $\beta$ (СEBPB). We found that exendin-4 inhibits SREBP1c and subsequent C/EBP $\beta$ activation, contributing to attenuation of ER stress and $\beta$-cell apoptosis.

\section{Materials and methods}

\section{Materials}

The sources of various reagents and materials were as follows: exendin-4, D-glucose, palmitate (PA), fatty acid-free BSA were from Sigma-Aldrich; anti-C/EBP $\beta$ and anti-lamin B antibodies were from Santa Cruz Biotechnology, Inc.; polyclonal antibody against SREBP1 (SREBF1) was from Abcam (Cambridge, MA, USA); MAB against ATF6 was from IMGENEX (San Diego, CA, USA); and anti-C/EBP homologous protein (CHOP), anti-caspase-3, anti-poly(ADP-ribose) polymerase (PARP), anti-PERK, anti-phospho-PERK, anti-phosphoIRE1 $\alpha$, anti-phospho-c-Jun N-terminal kinase (JNK), and antiphospho-eukaryotic initiation factor $2 \alpha$ (eIF2 $\alpha$ ) antibodies were from Cell Signaling Technology (Beverly, MA, USA). All other biochemical reagents were from Sigma or Invitrogen.

\section{Cell culture}

INS-1 pancreatic $\beta$ cells were maintained in RPMI 1640 (11 mM glucose, $1 \mathrm{mM}$ sodium pyruvate, and $10 \mathrm{mM}$ HEPES) containing 10\% fetal bovine serum (Gibco), $100 \mathrm{U} / \mathrm{ml}$ penicillin, and $100 \mu \mathrm{g} / \mathrm{ml}$ streptomycin. To examine the effect of exendin- 4 , cells were plated on six-well plates at $1.2 \times 10^{6}$ cells/well in media containing $25 \mathrm{mM}$ glucose and $400 \mu \mathrm{M}$ PA with or without $5 \mathrm{nM}$ exendin-4. The cells treated with vehicle as a control.

\section{PA preparation}

PA/BSA conjugates were prepared as described previously (Listenberger et al. 2001). Briefly, $20 \mathrm{mM}$ PA in 0.01 M NaOH was incubated at $70^{\circ} \mathrm{C}$ for $30 \mathrm{~min}$, and the PA was then mixed with 5\% BSA in PBS at a 3:1 molar ratio of BSA to PA.

\section{Cell viability assay}

Briefly, the cells were treated with RPMI media containing 3-(4,5-dimethylthiazol-2-yl)-2,5-diphenyltetrazolium bromide (MTT; $0.5 \mathrm{mg} / \mathrm{ml}$ ) for $1 \mathrm{~h}$ at $37^{\circ} \mathrm{C}$. Supernatants were discarded and isopropanol was then added. After incubating for $30 \mathrm{~min}$ at room temperature, cell viability was measured at $570 \mathrm{~nm}$ using a microplate reader (Molecular Devices Corp., Menlo Park, CA, USA).

\section{Quantitative real-time PCR}

Total RNA was prepared with RNAiso Plus (TaKaRa, Shiga, Japan), and cDNA was synthesized from $5 \mu \mathrm{g}$ RNA with

Published by Bioscientifica Ltd. 
TAKARA PrimeScript 1st strand cDNA synthesis kit. Quantitative real-time PCR (qRT-PCR) analysis was performed using SYBR master mix (Applied Biosystems) using the ABI 7900 Real-time PCR system according to the protocols provided by the manufacturer (Applied Biosystems). The sequences of the primer pairs are as follows: CHOP, (forward) 5'-GGAAGTGCATCTTCATACACCACC-3' and (reverse) 5'-TGACTGGAATCTGGAGAGCGAGGGC-3'; binding immunoglobulin protein (Bip), (forward) 5'-ACCAATTATCAGCAAACTCTATGGAA-3' and (reverse) 5'-CATCTTTTTCTGCTGTATCCTCTTCA-3'; SREBP1c, (forward) 5'-GGAGCCATGGATTGCACATT-3' and (reverse) 5'-AGGCCAGGGAAGTCACTGTCT-3'; C/EBP $\beta$, (forward) 5'-AAGATGCGCAACCTGGAGAC-3' and (reverse) 5'-CCTTCTTCTGCAGCCGCTC-3'; spliced XBP1, (forward) 5'-CTGAGTCCGAATCAGGTGCAG-3' and (reverse) 5'-ATCCATGGGAAGATGTTCTGG-3'; SREBP1a, (forward) 5'-ACACAGCGGTTTTGAACGACA-3' and (reverse) 5'-GCATCAAATAGGCCAGGGAA-3'; Bax, (forward) 5'-AGACACCTGAGCTGACCTTGGA-3' and (reverse) 5'-CGGAGACACTCGCTCAGCTT-3'; and cyclophilin, (forward) 5'-GGTCTTTGGGAAGGTGAAAGAA-3' and (reverse) 5'-GGTCTTTGGGAAGGTGAAAGAA-3'. The relative mRNA transcript levels were calculated according to the $2^{-\Delta C T}$ method, in which $\Delta C T$ represents the difference in threshold cycle values between the target mRNA and the cyclophilin internal control.

\section{Western blot analysis}

INS-1 cells were solubilized in lysis buffer $(50 \mathrm{mM}$ Tris$\mathrm{HCl}$, pH 7.4, 1\% Triton X-100, 150 mM NaCl, 1 mM EDTA, $1 \mathrm{mM} \mathrm{NaF}, 1 \mathrm{mM} \mathrm{Na}_{3} \mathrm{VO}_{4}, 1 \mathrm{mM}$ phenylmethylsulphonyl fluoride, and $1 \mathrm{mM}$ protease inhibitor cocktail). Protein $(30 \mu \mathrm{g})$ was subjected to SDS-PAGE electrophoresis and transferred to polyvinylidene difluoride membranes. The membranes were blocked with 5\% nonfat milk and incubated with specific antibodies. The blots were then incubated with HRP-conjugated anti-rabbit or anti-mouse antibodies. Signals were detected using the ECL detection system (Pierce, Rockford, IL, USA).

\section{Whole cell and nuclear protein extract preparation}

To prepare the whole cell extracts, cells were lysed in buffer containing 1\% Triton X-100, $50 \mathrm{mM}$ Tris- $\mathrm{HCl}$, $150 \mathrm{mM} \mathrm{NaCl}, 1 \mathrm{mM}$ EDTA, and protease inhibitors. Cell debris was removed after centrifugation $(10000 \boldsymbol{g})$ for $10 \mathrm{~min}$ at $4{ }^{\circ} \mathrm{C}$. Nuclear fractions were prepared from cells using a modification of the method of Sheng et al. (1995).
The cells were homogenized in buffer containing $10 \mathrm{mM}$ HEPES-KOH, pH 7.9, $10 \mathrm{mM} \mathrm{KCl,} 1.5 \mathrm{mM} \mathrm{MgCl}_{2}$, $1 \mathrm{mM}$ dithiothreitol, $0.1 \% \mathrm{NP} 40$, and protease inhibitors. Nuclei were separated by centrifugation $(7200 \boldsymbol{g})$ for $10 \mathrm{~min}$ at $4{ }^{\circ} \mathrm{C}$ and resuspended in nuclei resuspension buffer (10 mM HEPES-KOH, pH 7.9, $400 \mathrm{mM} \mathrm{KCl,}$ $0.1 \mathrm{mM}$ EDTA, 25\% glycerol, and protease). The mixture was stirred gently for $10 \mathrm{~min}$ at $4{ }^{\circ} \mathrm{C}$ and centrifuged at $1500 \mathrm{~g}$. The nuclear protein extract was recovered in supernatant. Protein concentration was determined using the BCA protein assay kit (Pierce).

\section{Transfection with siRNA}

SREBP1 siRNAs were purchased from Dharmacon Research (Lafeyette, CO, USA) as ON-target plus SMART pool. They targeted four regions of SREBP1 mRNA for interference. The target sequences were as follows: \#1 GCCCAGCCUUUGAGGAUAA, \#2 GGUCUAGCCUGCAGUUCUA, \#3 GGAUAUCUACAGUUGCUAA, and \#4 GAGGCAAAGCUGAAUAAAU. A synthetic cyclophilin B control pool siRNA (scramble siRNA) was used as a negative control. Cells were plated on six-well plates and transfected with $100 \mathrm{nM}$ siRNA and oligofectamine reagent (Invitrogen), according to the manufacturer's instructions. After $36 \mathrm{~h}$ of incubation, cells were treated with $25 \mathrm{mM}$ glucose and $400 \mu \mathrm{M}$ PA for $12 \mathrm{~h}$ with or without $5 \mathrm{nM}$ exendin- 4 .

\section{Statistical analysis}

Results are expressed as mean \pm s.e.m. of three separate experiments. ANOVA followed by Scheffe's multiple comparison test was used to determine the significance of any differences among more than two groups. $P<0.05$ was considered significant.

\section{Results}

\section{Exendin-4 protects INS-1 cells from HG/PA-induced toxicity}

Previously, it was reported that HG and PA synergistically induced glucolipotoxicity in $\beta$ cells and caused $\beta$-cell dysfunction (Zhou \& Grill 1994, El-Assaad et al. 2003, Donath \& Halban 2004, Tanabe et al. 2011). Consistent with previous reports, we found that glucose alone enhanced cell viability in a dose-dependent manner, whereas HG induced cell toxicity in the presence of PA (50\% cell viability in $25 \mathrm{mM}$ glucose/400 $\mu \mathrm{M}$ PA; Fig. 1A). Exendin-4 treatment significantly inhibited PA-induced

Published by Bioscientifica Ltd. 

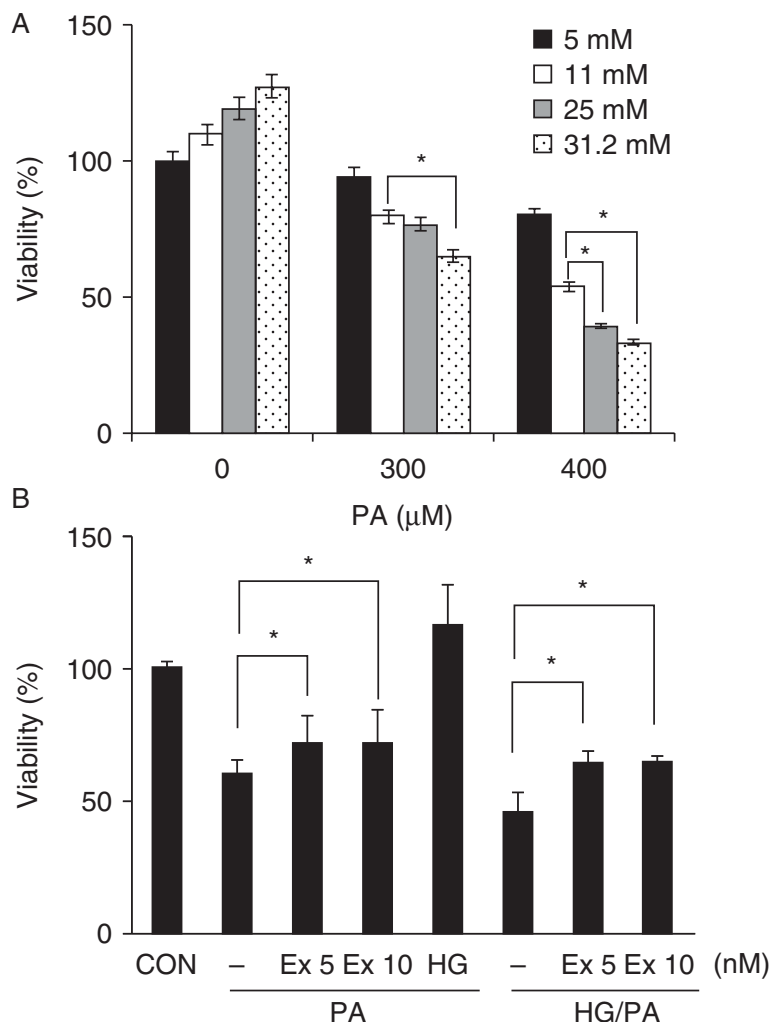

C

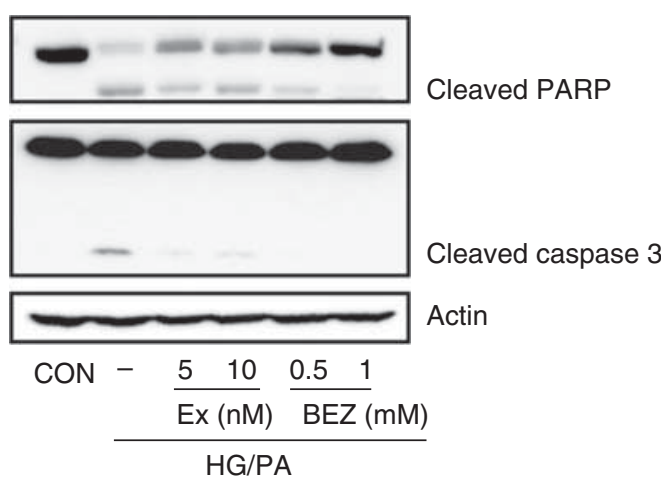

Figure 1

Exendin-4 treatment protects against $\mathrm{HG} / \mathrm{PA}$-induced glucolipotoxicity. (A) INS-1 cells were treated with various concentrations of glucose for $30 \mathrm{~min}$ before adding 300 or $400 \mu \mathrm{M}$ PA. After $24 \mathrm{~h}$, cell viability was determined by MTT assay. (B) INS-1 cells were treated with $25 \mathrm{mM}$ glucose (HG) and/or $400 \mu \mathrm{M}$ PA in the presence of 5 or $10 \mathrm{nM}$ exendin-4 (Ex) or vehicle (CON). After $24 \mathrm{~h}$, cell viability was determined by MTT assay. (C) INS-1 cells were treated as described in (B); after $24 \mathrm{~h}$, cells were harvested and activation of cleaved caspase- 3 and PARP was checked by immunoblotting with specific antibodies. Bezafibrate (BEZ) was used as positive control for anti-apoptotic effect. ${ }^{*} P<0.05$.

or HG/PA-induced cell death on INS-1 cells (Fig. 1B). Immunoblotting analysis showed that exendin-4 treatment inhibited the expression of cleaved forms of caspase- 3 and PARP, which were induced by HG/PA treatment
(Fig. 1C). Treatment with bezafibrate, as a positive control for the anti-apoptotic effect, similarly inhibited the expression of cleaved caspase- 3 and PARP. These results suggest that exendin- 4 has protective effects against HG/PA-induced INS-1 cell apoptosis.

\section{Exendin-4 inhibits ER stress signaling induced by HG/PA treatment}

To examine whether the protective effect of exendin- 4 against HG/PA-induced apoptosis is related to the inhibition of ER stress, INS-1 cells were treated with HG/PA in
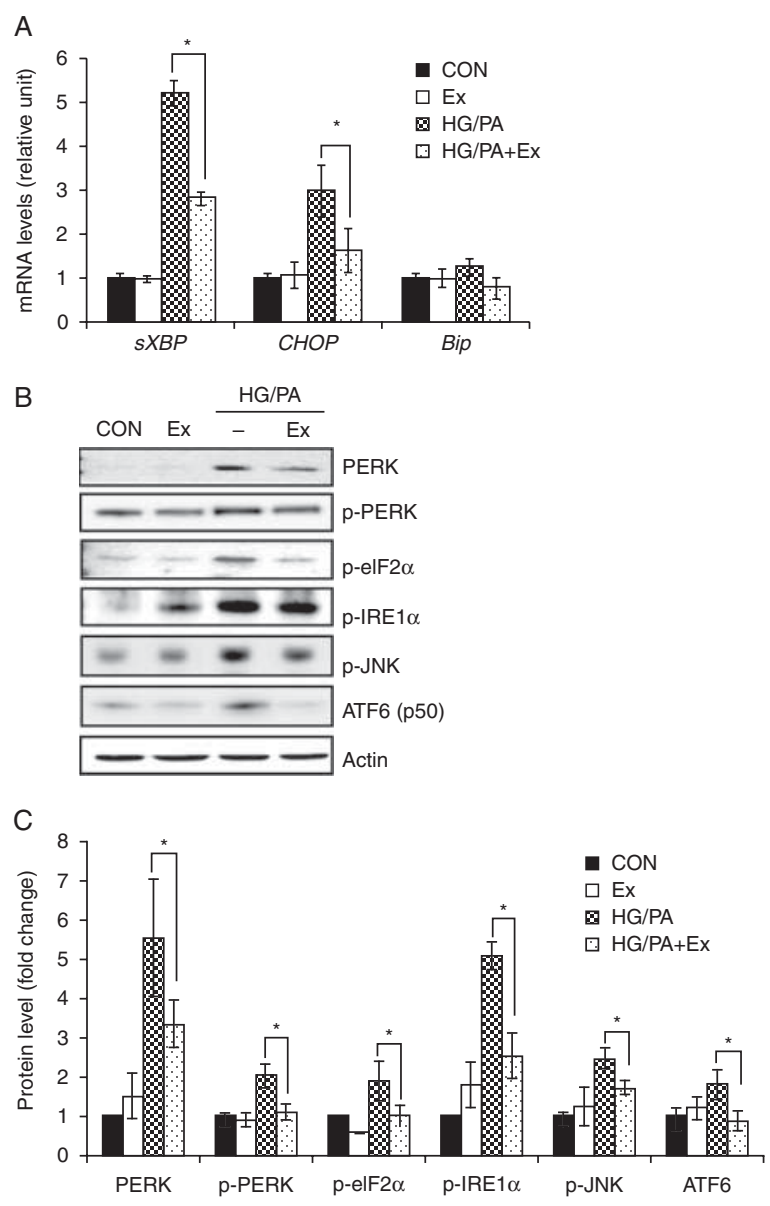

Figure 2

Exendin-4 inhibits HG/PA-induced expression of ER stress markers. (A) INS-1 cells were treated with vehicle (CON) or HG/PA in the absence or presence of $5 \mathrm{nM}$ exendin-4 (Ex) for $6 \mathrm{~h}$. Total RNA was isolated and mRNA expression of $\triangle X B P 1, C H O P$, and Bip were determined by qRT-PCR. Cyclophilin was used as control gene. (B) INS-1 cells were treated as described earlier for 12 or $18 \mathrm{~h}$ and total cell extracts were analyzed for PERK, p-PERK, p-eIF $2 \alpha, \mathrm{p}$-IRE $1 \alpha$, p-JNK, ATF6 (p50), and actin by immunoblotting using specific antibodies. (C) Quantitative analysis of western blots. Relative abundance of each band was estimated by densitometric analysis. Each bar represents the mean \pm s.E.M. from three independent experiments. ${ }^{*} P<0.05$.

Published by Bioscientifica Ltd. 
the absence or presence of $5 \mathrm{nM}$ exendin- 4 and the levels of ER stress-related markers were analyzed. As the PERK, IRE, and ATF6 pathways are the major signaling pathways of ER stress, we examined the expression level of specific makers of each pathway. HG/PA treatment induced the expression of $S X B P 1$ and CHOP mRNAs, and the expression of these mRNAs was significantly reduced by exendin-4 treatment (Fig. 2A). In addition, PERK, p-PERK, p-eIF2 $\alpha$, p-IRE1 $\alpha$, p-JNK, and cleaved ATF6 (p50) protein expression was increased by HG/PA treatment and the expression of these proteins was significantly reduced by exendin-4 treatment (Fig. 2B and C). mRNA expression of Bip was not changed by HG/PA or exendin- 4 treatment (Fig. 2A and $\mathrm{B}$ ). These results suggest that exendin-4 inhibits HG/PA-induced ER stress signaling, contributing to protection from $\beta$-cell apoptosis.

\section{Exendin-4 inhibits HG/PA-induced activation of SREBP1 and C/EBP $\beta$}

As it was reported that SREBP1 and C/EBP $\beta$ are involved in ER stress-induced cell death (Wang et al. 2005, Meir et al. 2010), we checked whether HG/PA treatment induced activation of these transcription factors. INS- 1 cells were incubated with $\mathrm{HG} / \mathrm{PA}$ for $2,4,6$, or $12 \mathrm{~h}$ and the mRNA expression of SREBP1C and $C / E B P \beta$ was examined by qRT-PCR. We found that both genes were increased by HG/PA treatment over time. Induction of SREBP1C was higher than that of $C / E B P \beta$, and induction time was as early as $2 \mathrm{~h}$ after treatment (Fig. 3A). Protein expression level was also increased by HG/PA treatment similar to that of mRNA (Fig. 3B). Finally, we observed an increase in the nuclear form of SREBP1 as early as after $2 \mathrm{~h}$ of HG/PA treatment, and the levels were sustained up to $12 \mathrm{~h}$ of treatment. By contrast, the expression of nuclear C/EBP $\beta$ did not substantially increase until after $6 \mathrm{~h}$ of treatment (Fig. 3C and D). These results indicate that SREBP1 activation precedes activation of C/EBP $\beta$ in INS-1 $\beta$ cells in response to $\mathrm{HG} / \mathrm{PA}$ treatment.

Next, to check whether exendin-4 regulates SREBP1c activation, cells were incubated with $\mathrm{HG} / \mathrm{PA}$ in the absence or presence of exendin- 4 for $12 \mathrm{~h}$ and mRNA, protein, and nuclear translocated protein levels were examined. We found that exendin- 4 significantly reduced the mRNA level (Fig. 4A) and both whole cell (Fig. 4B) and nuclear translocated protein levels (Fig. 4C and D) of SREBP1c induced by $\mathrm{HG} / \mathrm{PA}$ treatment. Nuclear translocation of $\mathrm{C} / \mathrm{EBP} \beta$ was also induced by $\mathrm{HG} / \mathrm{PA}$ treatment and it was reduced by exendin- 4 treatment (Fig. 4C and D).

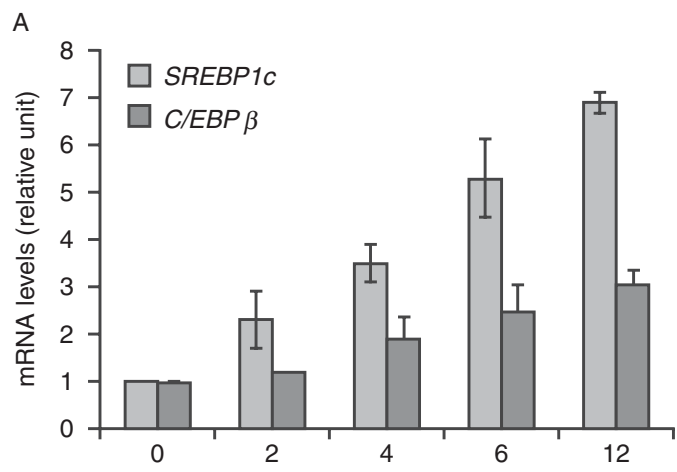

(h)

B

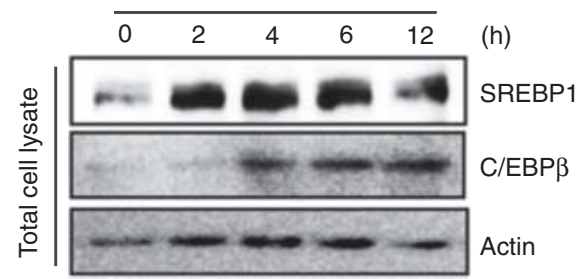

C
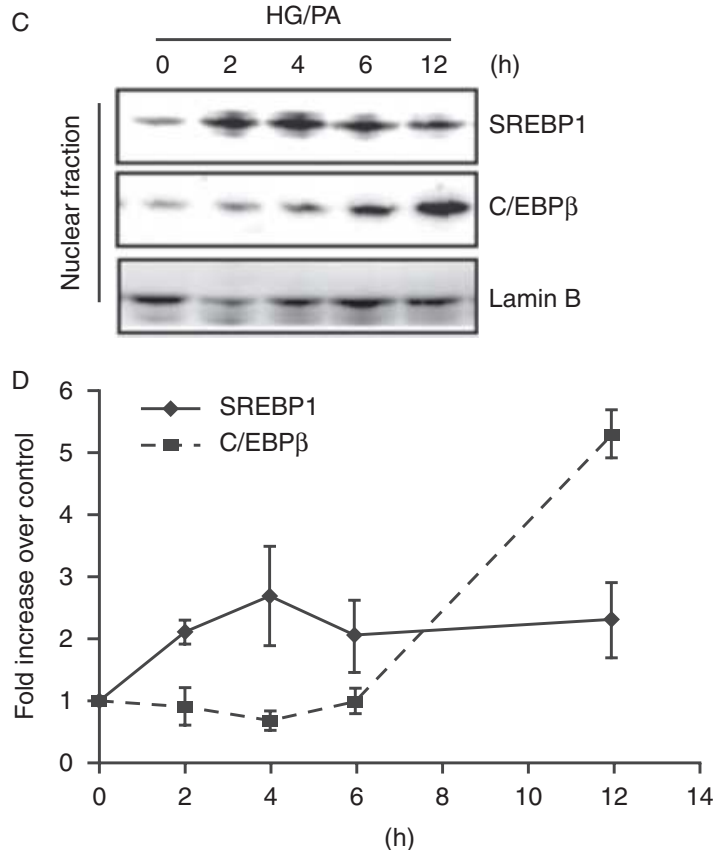

Figure 3

$\mathrm{HG} / \mathrm{PA}$ treatment increases expression levels of SREBP1 and C/EBP $\beta$ in INS-1 cells. INS- 1 cells were treated with $25 \mathrm{mM}$ glucose and $400 \mu \mathrm{M}$ palmitate (HG/PA) for the indicated times. (A) Total RNA was isolated and mRNA expressions of SREBP1C and C/EBP $\beta$ were examined by qRT-PCR. (B) Total cell lysate and $(C)$ nuclear protein extracts were analyzed by immunoblotting for SREBP1 and C/EBP $\beta$ using specific antibodies. (D) Quantitative analysis of western blots of nuclear protein extracts. The graph represents the fold change in protein levels compared with the control band (lamin B) on western blots that were quantitated by densitometric analysis.

Published by Bioscientifica Ltd. 
A

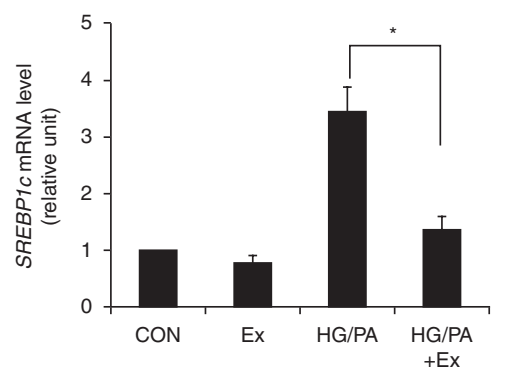

B
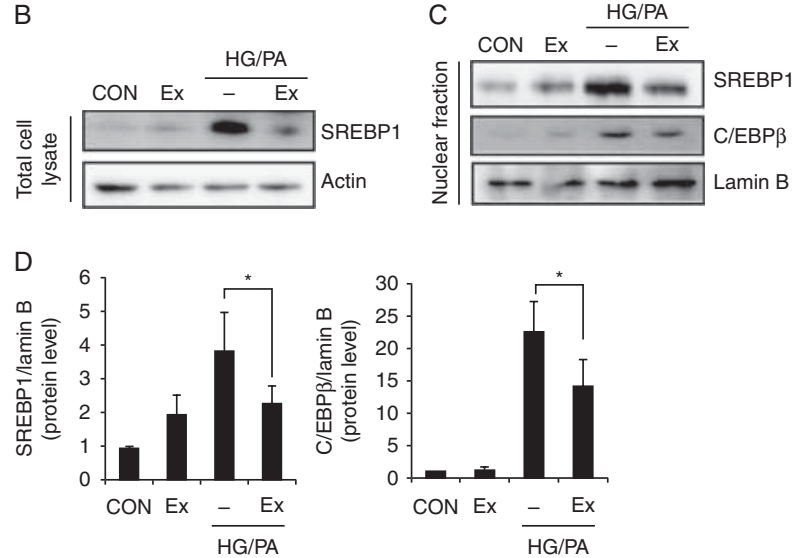

Figure 4

Exendin- 4 reduces the expression of SREBP1 and C/EBP $\beta$ in HG/PA-treated INS-1 cells. (A) INS-1 cells were treated with vehicle (CON) or $25 \mathrm{mM}$ glucose and $400 \mu \mathrm{M}$ palmitate (HG/PA) in the absence or presence of $5 \mathrm{nM}$ exendin-4 (Ex) for $12 \mathrm{~h}$. Total mRNA was isolated and mRNA expression of SREBP1C was examined by qRT-PCR. (B) INS-1 cells were treated as described in (A) and total cell extract was analyzed by immunoblotting for SREBP1 and $\beta$-actin using specific antibodies. (C) Nuclear proteins were harvested and analyzed by immunoblotting for SREBP1, C/EBP $\beta$, and lamin B using specific antibodies. (D) Quantitative analysis of western blots of nuclear proteins. The relative fold change in C/EBP $\beta$ and SREBP1 to its control band (lamin B) was quantitated by densitometric analysis. ${ }^{*} P<0.05$.

\section{Exendin-4 inhibits HG/PA-induced ER stress by downregulation of SREBP/1 activation}

To examine whether SREBP1c regulates $C E B P / \beta$ expression, HG/PA-induced ER stress, and subsequently $\beta$-cell apoptosis, we inhibited SREBP1c by SREBP1c siRNA in INS-1 cells and then treated them with HG/PA. mRNA level of SREBP1c in siRNA-transfected INS-1 cells was about $48 \%$ of INS-1 cells transfected with scramble siRNA under HG/PA conditions. We also confirmed that SREBP1a, another splicing form of SREBP1 (Shimomura et al. 1997), was not affected by HG/PA and SREBP1c siRNA treatment (Fig. 5A). We found that inhibition of SREBP1C significantly reduced HG/PA-induced Bax mRNA (Fig. 5B) and also reduced cleaved PARP (Fig. 5C), and the effect was similar to exendin-4 treatment. As shown in Fig. 5D, SREBP1c downregulation recovered cell viability reduced by HG/PA treatment.

When we examined the expression of C/EBP $\beta$ and related ER proteins, we found that inhibition of SREBP1c significantly inhibited HG/PA-induced nuclear translocation of C/EBP $\beta$ and expression of PERK, p-PERK, and p-eIF2 $\alpha$ (Fig. 6A and B). In addition, induction of $s X B P$ mRNA expression by HG/PA was significantly reduced in SREBP1C siRNA-transfected cells similar to exendin-4 treatment of HG/PA-treated cell (Fig. 6C).

\section{Discussion}

ER stress participates in $\beta$-cell dysfunction and death during the development of type 2 diabetes (Ozcan et al. 2004, Laybutt et al. 2007). High levels of glucose and increased lipids (glucolipotoxicity) are known to be a cause of $\beta$-cell damage and induce ER stress (El-Assaad et al. 2003, Poitout 2008). GLP1 and GLP1 receptor agonists have been reported to inhibit ER stress and prevent $\beta$-cell death induced by these toxicities. However, the molecular mechanisms regarding how GLP1 receptor activation reduces ER stress and prevents $\beta$-cell apoptosis are not well known. In our study, we found that expression level of markers of the PERK, IRE1, and ATF6 ER stress pathways were elevated in HG/PA-treated cells and reduced by treatment with exendin-4, a GLP1 agonist. These results are consistent with previous studies showing that exendin- 4 reduces ER stress and prevents $\beta$-cell apoptosis (Tsunekawa et al. 2007).

Although three branches of ER stress signaling were involved in the anti-apoptotic effect of exendin-4, we found that Bip mRNA expression was not changed in our experimental condition, in which we treated INS-1 cells with HG/PA for $6 \mathrm{~h}$, although mRNA levels of CHOP, one of the transcription factors activated by ATF6, was increased by glucolipotoxicity and was reduced in exendin-4-treated cells. Others have shown that different stimulation conditions can have differential effects on the regulation of Bip mRNA and protein. For example, $30 \mathrm{mM}$ glucose for $48 \mathrm{~h}$ induced Bip mRNA levels (Wang et al. 2005), but $0.5 \mathrm{mM}$ PA treatment for $14 \mathrm{~h}$ did not alter Bip mRNA levels (Cunha et al. 2009). Therefore, the transcriptional regulation of ER stress signaling might be different depending on the cell types or stimulus condition. Further studies will be required to understand the detailed molecular mechanisms for these differential effects.

Studies on the mechanisms showed that the antiapoptotic protein, JunB, was involved in the protective

Published by Bioscientifica Ltd 
A

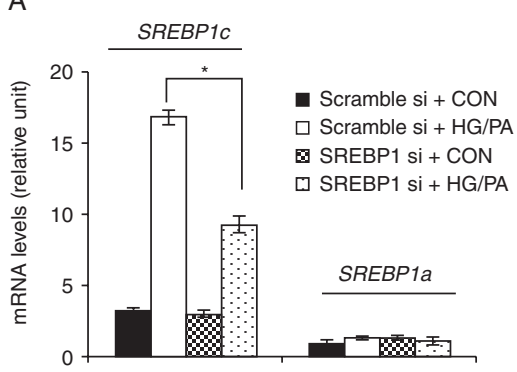

C

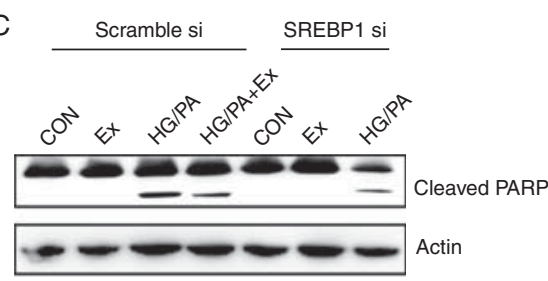

B
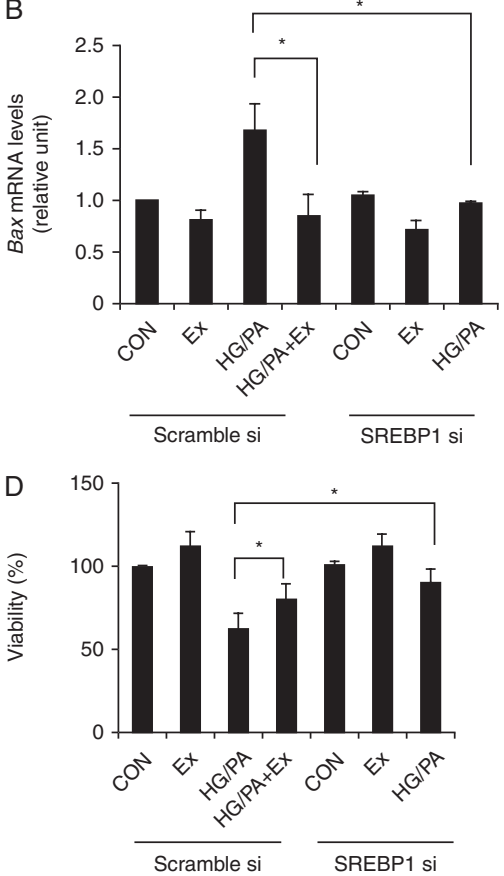

Figure 5

SREBP1C downregulation inhibits HG/PA-induced $\beta$-cell apoptosis. (A) INS-1 cells were transiently transfected with cyclophilin $B$ control pool siRNA as a negative control (scramble si) or SREBP1 siRNA (SREBP1 si). After $36 \mathrm{~h}$, cells were treated with $25 \mathrm{mM}$ glucose and $400 \mu \mathrm{M}$ palmitate (HG/PA) or vehicle (CON). Total RNA was isolated and mRNA expression of SREBP1C and SREBP1a was determined by qRT-PCR. (B) After transfection with siRNA, INS-1 cells were treated with HG/PA in the absence or presence of

effect of GLP1 receptor agonists against ER stress (Cunha et al. 2009). As well, exendin-4 significantly induced ATF4 expression by ER stress and accelerated recovery from ER stress-mediated translational repression in a protein kinase A-dependent manner (Yusta et al. 2006). However, the exact mechanisms for ER stress regulation by GLP1 in glucolipotoxicity are not clear.

Activation of transcription factors that control lipogenic gene expression, particularly SREBP, is implicated in ER stress. Previous studies demonstrated that overexpression of the active nuclear form of SREBP1c in insulinsecreting cells and isolated islets results in $\beta$-cell lipotoxicity (Andreolas et al. 2002, El Saadawi et al. 2010). ER stress inducers enhance SREBP1 binding to the insulin receptor substrate-2 promoter and suppress its expression, suggesting that SREBP1 activation caused by ER stress is involved in $\beta$-cell glucolipotoxicity (Wang et al. 2005). As well, treatment with some antidiabetic drugs or hormones including metformin, troglitazone, and leptin can prevent diabetes-associated lipotoxicity in diabetic animals through inhibition of SREBP1c activation
$5 \mathrm{nM}$ exendin-4 (Ex). After $6 \mathrm{~h}$, total RNA was isolated and mRNA expression of Bax was determined by qRT-PCR. (C) Cells were treated as described earlier and harvested. Total cell lysate was extracted and western blotting was performed to detect cleaved PARP and actin protein. (D) Cells were treated as described earlier, and cell viability was determined by MTT assay. Each bar represents the mean \pm s.E.M. from three independent experiments. ${ }^{*} P<0.05$.

(Shimomura et al. 1999, Kakuma et al. 2000, Lin et al. 2000, Xu et al. 2004). Therefore, we examined the activation and expression of SREBP1c in HG/PA-treated INS- 1 cells and regulation by exendin- 4 . We found that exendin-4 treatment inhibited the mRNA and protein levels of SREBP1 induced by HG/PA treatment. Consequently, nuclear translocated SREBP1c induced by HG/PA treatment was reduced by exendin- 4 treatment. We also found that SREBP1c was involved in the anti-apoptotic effect of exendin-4 on another insulin-secreting cell line, MIN-6, suggesting that exendin-4 generally prevented glucolipotoxicity through suppression of SREBP1c in $\beta$ cells (data not shown).

$\mathrm{C} / \mathrm{EBP} \beta$ is increased in diabetic islets, and accumulation of $\mathrm{C} / \mathrm{EBP} \beta$ increases the vulnerability of cells to $\mathrm{ER}$ stress (Matsuda et al. 2010, Meir et al. 2010). It was reported that LIP, a dominant-negative, truncated $\mathrm{C} / \mathrm{EBP} \beta$ variant form, augmented thapsigargin- or tunicamycin-induced cell death via forming a LIP/LAP heterodimer and inducing CHOP expression (Meir et al. 2010). Moreover, accumulation of $\mathrm{C} / \mathrm{EBP} \beta$ reduced glucose-regulated

Published by Bioscientifica Ltd. 

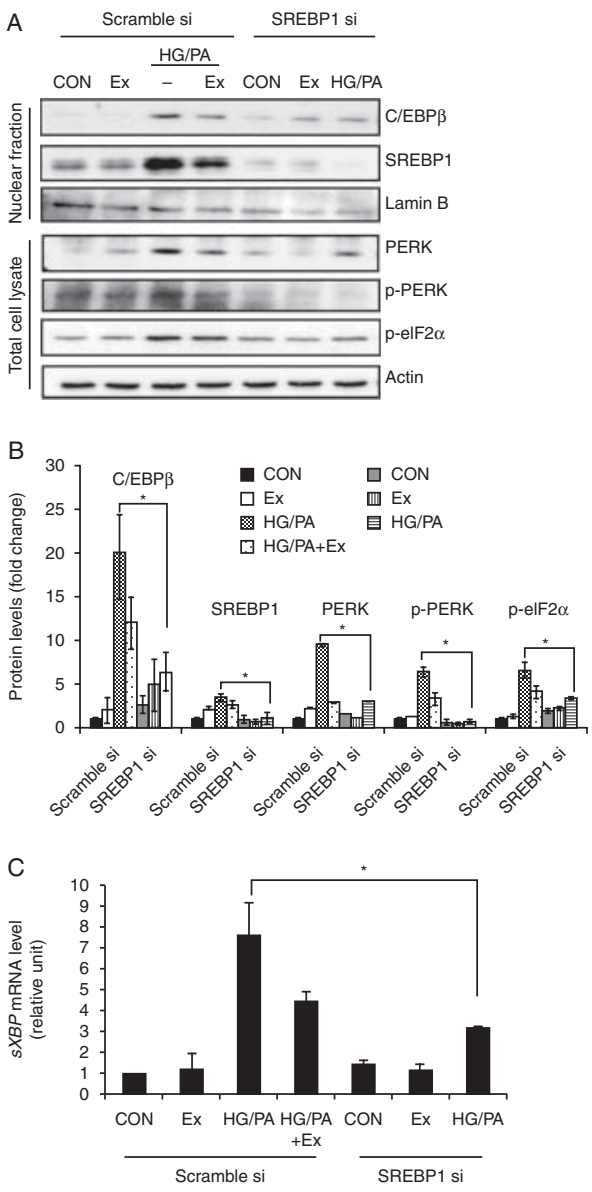

\section{Figure 6}

SREBP1 downregulation inhibits HG/PA-induced expression of C/EBP $\beta$ and ER stress markers. INS-1 cells were treated as described in Fig. $5 \mathrm{C}$, and cells were harvested. (A) Nuclear protein was extracted and C/EBP $\beta$, SREBP1, and lamin B were analyzed by western blotting. Total cell lysate was extracted and western blotting was performed to detect PERK, p-PERK, p-eIF2 $\alpha$, and actin protein. (B) Quantitative analysis of western blots. Relative abundance of each band was estimated by densitometric analysis. (C) Total RNA was isolated and mRNA expression of $s X B P 1$ was determined by qRT-PCR. Each bar represents the mean \pm S.E.M. from three independent experiments. ${ }^{\star} P<0.05$.

protein of $78 \mathrm{kDa}$ (GRP78, Bip) due to the suppressed transactivation of ATF $6 \alpha$, thereby enhancing susceptibility to ER stress (Matsuda et al. 2010). In our study, $\mathrm{C} / \mathrm{EBP} \beta$ translocation to the nucleus was observed in HG/PA-treated INS- 1 cells, and exendin- 4 treatment inhibited HG/PA-induced activation of C/EBP $\beta$.

We found that the increase in SREBP1c levels in the nucleus was seen before increases in C/EBP $\beta$. The expression of $S R E B P 1 C$ and $C / E B P \beta$ is closely correlated in several models of adipogenesis; however, the sequence of activation is still debated (Le Lay et al. 2002, Payne et al. 2010). Therefore, we investigated whether downregulation of SREBP1c affects activation of C/EBP $\beta$ and ER stress-induced $\beta$-cell death. We found that downregulation of SREBP1c decreased the activation of C/EBP $\beta$ and also reduced sXBP, PERK, p-PERK, and p-eIF $2 \alpha$, resulting in increased cell viability in $\mathrm{HG} / \mathrm{PA}$-treated cells. These results suggest that downregulation of SREBP1c by exendin- 4 is one mechanism for protection against glucolipotoxic ER stress. As the regulation of SREBP1c by exendin- 4 has not been investigated, the detailed mechanisms are not known. However, activation of protein kinase $\mathrm{A}$, one of the major signaling pathways of exendin-4, represses SREBP1c expression via phosphorylation of liver $X$ receptor, which causes impaired DNA binding activity by preventing LXR/RXR dimerization (Yamamoto et al. 2007). Therefore, protein kinase A-dependent signaling might be involved in the regulation of SREBP1c by exendin-4.

In summary, we have demonstrated that SREBP1cmediated C/EBP $\beta$ activation is one of the mechanisms of glucolipotoxic ER stress in INS-1 cells. Moreover, exendin- 4 protects $\beta$ cells against ER stress through downregulation of SREBP1c. The present identification of the apoptotic ER stress pathways and downstream signaling modulated by GLP1 is an important step for the development of targeted approaches to alleviate $\beta$-cell ER stress in type 2 diabetes.

\section{Declaration of interest}

The authors declare that there is no conflict of interest that could be perceived as prejudicing the impartiality of the research reported.

\section{Funding}

This study was supported by a National Research Foundation of Korea (NRF) grant funded by the Korea government (MEST) (no. 2009-0079342), the Basic Science Research Program through the National Research Foundation of Korea (NRF) funded by the Ministry of Education, Science and Technology (no. 2010-0009378), and the Innovative Research Institute for Cell Therapy (A062260).

\section{Acknowledgements}

The authors thank Dr Ann Kyle for editorial assistance.

\section{References}

Andreolas C, da Silva Xavier G, Diraison F, Zhao C, Varadi A, Lopez-Casillas F, Ferre P, Foufelle F \& Rutter GA 2002 Stimulation of acetyl-CoA carboxylase gene expression by glucose requires insulin release and sterol regulatory element binding protein $1 \mathrm{c}$ in pancreatic MIN6 $\beta$-cells. Diabetes 51 2536-2545. (doi:10.2337/diabetes.51.8.2536) 
Araki E, Oyadomari S \& Mori M 2003 Impact of endoplasmic reticulum stress pathway on pancreatic $\beta$-cells and diabetes mellitus. Experimental Biology and Medicine 228 1213-1217.

Cunha DA, Ladriere L, Ortis F, Igoillo-Esteve M, Gurzov EN, Lupi R, Marchetti P, Eizirik DL \& Cnop M 2009 Glucagon-like peptide-1 agonists protect pancreatic $\beta$-cells from lipotoxic endoplasmic reticulum stress through upregulation of BiP and JunB. Diabetes $\mathbf{5 8}$ 2851-2862. (doi:10.2337/db09-0685)

Donath MY \& Halban PA 2004 Decreased $\beta$-cell mass in diabetes: significance, mechanisms and therapeutic implications. Diabetologia 47 581-589. (doi:10.1007/s00125-004-1336-4)

Donath MY, Ehses JA, Maedler K, Schumann DM, Ellingsgaard H, Eppler E \& Reinecke M 2005 Mechanisms of $\beta$-cell death in type 2 diabetes. Diabetes 54(Suppl 2) S108-S113. (doi:10.2337/diabetes.54.suppl_2. S108)

Doyle ME \& Egan JM 2007 Mechanisms of action of glucagon-like peptide 1 in the pancreas. Pharmacology \& Therapeutics 113 546-593. (doi:10.1016/j.pharmthera.2006.11.007)

El-Assaad W, Buteau J, Peyot ML, Nolan C, Roduit R, Hardy S, Joly E, Dbaibo G, Rosenberg L \& Prentki M 2003 Saturated fatty acids synergize with elevated glucose to cause pancreatic $\beta$-cell death. Endocrinology 144 4154-4163. (doi:10.1210/en.2003-0410)

El Saadawi GM, Azevedo R, Castine M, Payne V, Medvedeva O, Tseytlin E, Legowski E, Jukic D \& Crowley RS 2010 Factors affecting feelingof-knowing in a medical intelligent tutoring system: the role of immediate feedback as a metacognitive scaffold. Advances in Health Sciences Education: Theory and Practice 15 9-30. (doi:10.1007/s10459009-9162-6)

Ferdaoussi M, Abdelli S, Yang JY, Cornu M, Niederhauser G, Favre D, Widmann C, Regazzi R, Thorens B, Waeber G et al. 2008 Exendin-4 protects $\beta$-cells from interleukin- $1 \beta$-induced apoptosis by interfering with the c-Jun NH2-terminal kinase pathway. Diabetes 57 1205-1215. (doi:10.2337/db07-1214)

Foretz M, Pacot C, Dugail I, Lemarchand P, Guichard C, Le Liepvre X, Berthelier-Lubrano C, Spiegelman B, Kim JB, Ferre P et al. 1999 ADD1/SREBP-1c is required in the activation of hepatic lipogenic gene expression by glucose. Molecular and Cellular Biology 19 3760-3768.

Jhala US, Canettieri G, Screaton RA, Kulkarni RN, Krajewski S, Reed J, Walker J, Lin X, White M \& Montminy M 2003 cAMP promotes pancreatic $\beta$-cell survival via CREB-mediated induction of IRS2. Genes and Development 17 1575-1580. (doi:10.1101/gad.1097103)

Kakuma T, Lee Y, Higa M, Wang Z, Pan W, Shimomura I \& Unger RH 2000 Leptin, troglitazone, and the expression of sterol regulatory element binding proteins in liver and pancreatic islets. PNAS 97 8536-8541. (doi:10.1073/pnas.97.15.8536)

Lai E, Teodoro T \& Volchuk A 2007 Endoplasmic reticulum stress: signaling the unfolded protein response. Physiology 22 193-201. (doi:10.1152/ physiol.00050.2006)

Laybutt DR, Preston AM, Akerfeldt MC, Kench JG, Busch AK, Biankin AV \& Biden TJ 2007 Endoplasmic reticulum stress contributes to $\beta$ cell apoptosis in type 2 diabetes. Diabetologia 50 752-763. (doi:10.1007/ s00125-006-0590-z)

Le Lay S, Lefrere I, Trautwein C, Dugail I \& Krief S 2002 Insulin and sterolregulatory element-binding protein-1c (SREBP-1C) regulation of gene expression in 3T3-L1 adipocytes. Identification of CCAAT/enhancerbinding protein $\beta$ as an SREBP-1C target. Journal of Biological Chemistry 277 35625-35634. (doi:10.1074/jbc.M203913200)

Lin HZ, Yang SQ, Chuckaree C, Kuhajda F, Ronnet G \& Diehl AM 2000 Metformin reverses fatty liver disease in obese, leptin-deficient mice. Nature Medicine 6 998-1003. (doi:10.1038/79697)

Listenberger LL, Ory DS \& Schaffer JE 2001 Palmitate-induced apoptosis can occur through a ceramide-independent pathway. Journal of Biological Chemistry 276 14890-14895. (doi:10.1074/jbc.M010286200)

Matsuda T, Kido Y, Asahara S, Kaisho T, Tanaka T, Hashimoto N, Shigeyama Y, Takeda A, Inoue T, Shibutani Y et al. 2010 Ablation of C/EBP $\beta$ alleviates ER stress and pancreatic $\beta$ cell failure through the
GRP78 chaperone in mice. Journal of Clinical Investigation 120 115-126. (doi:10.1172/JCI39721)

Meir O, Dvash E, Werman A \& Rubinstein M 2010 C/EBP- $\beta$ regulates endoplasmic reticulum stress-triggered cell death in mouse and human models. PLoS ONE 5 e9516. (doi:10.1371/journal.pone. 0009516)

Ozcan U, Cao Q, Yilmaz E, Lee AH, Iwakoshi NN, Ozdelen E, Tuncman G, Gorgun C, Glimcher LH \& Hotamisligil GS 2004 Endoplasmic reticulum stress links obesity, insulin action, and type 2 diabetes. Science 306 457-461. (doi:10.1126/science.1103160)

Payne VA, Au WS, Lowe CE, Rahman SM, Friedman JE, O'Rahilly S \& Rochford JJ 2010 C/EBP transcription factors regulate SREBP1c gene expression during adipogenesis. Biochemical Journal 425 215-223. (doi:10.1042/BJ20091112)

Plaisance V, Perret V, Favre D, Abderrahmani A, Yang JY, Widmann C \& Regazzi R 2009 Role of the transcriptional factor C/EBP $\beta$ in free fatty acid-elicited $\beta$-cell failure. Molecular and Cellular Endocrinology $\mathbf{3 0 5}$ 47-55. (doi:10.1016/j.mce.2008.12.005)

Poitout V 2008 Glucolipotoxicity of the pancreatic $\beta$-cell: myth or reality? Biochemical Society Transactions 36 901-904. (doi:10.1042/BST0360901)

Poitout V \& Robertson RP 2008 Glucolipotoxicity: fuel excess and $\beta$-cell dysfunction. Endocrine Reviews 29 351-366. (doi:10.1210/er.2007-0023)

Robertson RP, Harmon J, Tran PO \& Poitout V $2004 \beta$-Cell glucose toxicity, lipotoxicity, and chronic oxidative stress in type 2 diabetes. Diabetes 53(Suppl 1) S119-S124. (doi:10.2337/diabetes.53.2007.S119)

Sheng Z, Otani H, Brown MS \& Goldstein JL 1995 Independent regulation of sterol regulatory element-binding proteins 1 and 2 in hamster liver. PNAS 92 935-938. (doi:10.1073/pnas.92.4.935)

Shimomura I, Shimano H, Horton JD, Goldstein JL \& Brown MS 1997 Differential expression of exons 1a and 1c in mRNAs for sterol regulatory element binding protein-1 in human and mouse organs and cultured cells. Journal of Clinical Investigation 99 838-845. (doi:10.1172/ JCI119247)

Shimomura I, Hammer RE, Ikemoto S, Brown MS \& Goldstein JL 1999 Leptin reverses insulin resistance and diabetes mellitus in mice with congenital lipodystrophy. Nature 401 73-76. (doi:10.1038/ 43448)

Tanabe K, Liu Y, Hasan SD, Martinez SC, Cras-Meneur C, Welling CM, Bernal-Mizrachi E, Tanizawa Y, Rhodes CJ, Zmuda E et al. 2011 Glucose and fatty acids synergize to promote $\beta$-cell apoptosis through activation of glycogen synthase kinase $3 \beta$ independent of JNK activation. PLoS ONE 6 e18146. (doi:10.1371/journal.pone.0018146)

Tourrel C, Bailbe D, Meile MJ, Kergoat M \& Portha B 2001 Glucagon-like peptide- 1 and exendin- 4 stimulate $\beta$-cell neogenesis in streptozotocintreated newborn rats resulting in persistently improved glucose homeostasis at adult age. Diabetes 50 1562-1570. (doi:10.2337/ diabetes.50.7.1562)

Tsunekawa S, Yamamoto N, Tsukamoto K, Itoh Y, Kaneko Y, Kimura T, Ariyoshi Y, Miura Y, Oiso Y \& Niki I 2007 Protection of pancreatic $\beta$-cells by exendin- 4 may involve the reduction of endoplasmic reticulum stress; in vivo and in vitro studies. Journal of Endocrinology 193 65-74. (doi:10.1677/JOE-06-0148)

Wang H, Kouri G \& Wollheim CB 2005 ER stress and SREBP-1 activation are implicated in $\beta$-cell glucolipotoxicity. Journal of Cell Science $\mathbf{1 1 8}$ 3905-3915. (doi:10.1242/jcs.02513)

Weber SM, Chambers KT, Bensch KG, Scarim AL \& Corbett JA 2004 PPAR $\gamma$ ligands induce ER stress in pancreatic $\beta$-cells: ER stress activation results in attenuation of cytokine signaling. American Journal of Physiology. Endocrinology and Metabolism 287 E1171-E1177. (doi:10.1152/ajpendo. 00331.2004)

Wu J \& Kaufman RJ 2006 From acute ER stress to physiological roles of the unfolded protein response. Cell Death and Differentiation 13 374-384. (doi:10.1038/sj.cdd.4401840)

Xu A, Yin S, Wong L, Chan KW \& Lam KS 2004 Adiponectin ameliorates dyslipidemia induced by the human immunodeficiency virus protease 
inhibitor ritonavir in mice. Endocrinology 145 487-494. (doi:10.1210/ en.2003-1140)

Yamamoto T, Shimano H, Inoue N, Nakagawa Y, Matsuzaka T, Takahashi A, Yahagi N, Sone H, Suzuki H, Toyoshima H et al. 2007 Protein kinase A suppresses sterol regulatory element-binding protein1C expression via phosphorylation of liver $\mathrm{X}$ receptor in the liver. Journal of Biological Chemistry 282 11687-11695. (doi:10.1074/jbc. M611911200)

Ye J, Rawson RB, Komuro R, Chen X, Dave UP, Prywes R, Brown MS \& Goldstein JL 2000 ER stress induces cleavage of membrane-bound ATF6 by the same proteases that process SREBPs. Molecular Cell 6 1355-1364. (doi:10.1016/S1097-2765(00)00133-7)

Yusta B, Baggio LL, Estall JL, Koehler JA, Holland DP, Li H, Pipeleers D, Ling Z \& Drucker DJ 2006 GLP-1 receptor activation improves $\beta$ cell function and survival following induction of endoplasmic reticulum stress. Cell Metabolism 4 391-406. (doi:10.1016/j.cmet.2006.10.001)

Zhou YP \& Grill VE 1994 Long-term exposure of rat pancreatic islets to fatty acids inhibits glucose-induced insulin secretion and biosynthesis through a glucose fatty acid cycle. Journal of Clinical Investigation $\mathbf{9 3}$ 870-876. (doi:10.1172/JCI117042)

Received in final form 27 November 2012

Accepted 19 December 2012

Accepted Preprint published online 19 December 2012
Published by Bioscientifica Ltd. 